\title{
Systematic Review of the Role of Sedation in Diagnostic Spinal Interventional Techniques
}

Howard S. Smith, MD ${ }^{1}$, Pradeep Chopra, MD², Vikram B. Patel, MD³, Michael E. Frey, MD, and Rahul Rastogi, MD

From: 'Albany Medical College, Albany, NY; ${ }^{2}$ Brown Medical School, Providence, $\mathrm{Rl}^{3}{ }^{3} \mathrm{ACMI}$ Pain Care, Algonquin, IL; ${ }^{4}$ Barnes Hospital, Washington University, St. Louis, MO; and ${ }^{5}$ Advanced Pain Management and

Spine Specialists, Fort Myers, FL.

Dr. Smith is Associate Professor and Academic Director of

Pain Management for Albany Medical College Department of Anesthesiology, Albany, NY. Dr. Chopra is Assistant Professor of Medicine, Department of Medicine,

Division of Biology and Medicine,

Brown Medical School; Assistant

Professor of Anesthesiology, Boston University School of Medicine; and Medical Director, Interventional Pain Center, Pawtucket, RI.

Dr. Patel is President and Medical Director of ACMI Pain Care, Algonquin, LL.

Dr. Rastogi is Assistant Professor, Department of Anesthesiology, Barnes

Hospital, Washington University, St. Louis, MO.

Dr. Frey is with Advanced Pain Management and Spine Specialists, Director of Interventional Physiatry, Fort Myers, Florida, and Assistant Clinical Professor, Adjunct Faculty, Virginia Commonwealth University, Fort Myers, FL.

Address correspondence: Howard S. Smith, MD Associate Professor \& Academic Director of Pain Management Albany Medical College

Department of Anesthesiology 47 New Scotland Avenue; MC-131

Albany, New York 12208

E-mail: smithh@mail.amc.edu Disclaimer: There was no external funding in the preparation of this manuscript.

Conflict of interest: None.

Manuscript received: 10/12/2008 Accepted for publication:11/05/2008

Free full manuscript: www.painphysicianjournal.com
Background: There is ongoing controversy regarding the validity of controlled diagnostic blocks due to variability in sensitivity, specificity, and accuracy. Consequently, identification of false-positive rates, false-negative rates, and placebo responses is crucial. The reasons described for false-positive responses to diagnostic anesthetic blocks are many; however, sedation and psychological factors have been implied as causes. Further, there is no consensus with regards to sedation prior to controlled diagnostic blocks and their influence on the accuracy and validity of a diagnosis.

Study Design: A systematic review of the literature evaluating the influence of sedation on diagnostic spinal interventional techniques.

Objectives: To systematically assess the quality of clinical studies evaluating the diagnostic accuracy of controlled diagnostic blocks in the diagnosis of chronic spinal pain.

Methods: A comprehensive evaluation of the literature relating to sedation in diagnostic interventional techniques was performed. The methodologic quality assessment of the studies was carried out by utilizing Agency for Healthcare Research and Quality (AHRQ) methodologic quality criteria with scores of 50 or higher included in the assessment of the level of evidence. Level of evidence was based on the U.S. Preventive Services Task Force (USPSTF) criteria for the assessment of accuracy of diagnostic studies.

Limitations: All 3 of the studies were produced by one group of authors. Thus paucity of the literature on the subject of facet joint pain and the lack of literature on the subjects of discogenic pain and sacroiliac joint pain are major limitations.

Results: Three studies were identified which met inclusion and methodologic assessment quality criteria. Sedation can be a confounding factor in a small population of patients specifically if fentanyl is employed and non-stringent criteria are followed. Based on the 3 randomized double-blind trials with stringent criteria utilizing $80 \%$ pain relief and the ability to perform prior painful movements without any significant pain following the diagnostic injection in evaluation of facet joint pain, the indicated evidence is Level II-1.

Conclusion: This systematic review provides no significant evidence of the influence of sedation either with midazolam or fentanyl in the evaluation of cervical and lumbar facet joint pain with controlled cervical and lumbar facet joint nerve blocks with an indicated evidence of Level II-1, with application of stringent criteria of at least $80 \%$ pain relief and the ability to perform previously painful movements after the diagnostic blocks.

Key words: Sedation, chronic spinal pain, anxiolytics, analgesics, controlled diagnostic nerve blocks, opioids, benzodiazepines, zygapophysial or facet joint blocks, provocation discography, sacroiliac joint injections

Pain Physician 2009; 12:1:195-206 
volution and phenomenal growth of interventional pain management (IPM) (15) has led almost all interventional pain physicians to encounter patients with chronic, persistent spinal pain with psychological problems who also have been exposed to opioids (6-11). Among chronic pain disorders, pain arising from various structures of the spine constitutes the majority of the problems (6). However, due to the inability of physical examination, clinical symptoms, radiologic evaluation, and nerve conduction studies to provide a reliable diagnosis of the structural origin of pain in a patient with chronic pain without disc herniation and radiculitis, controlled diagnostic blocks are considered the only means of reliable diagnosis of spinal pain (6$8,12-16)$. The most commonly performed diagnostic interventional techniques include diagnostic facet joint nerve blocks, discography, and sacroiliac joint injections (6). Based on the controlled evaluations, lumbar facet joint pain has been demonstrated in $15 \%$ to $45 \%$ of the patients, with a false-positive rate of $17 \%$ to $50 \%(17-29)$, discogenic pain has been demonstrated in $26 \%$ to $39 \%(17,30)$, with a significant alleged false-positive rate (31), with a prevalence of sacroiliac joint pain in $10 \%$ to $26 \%$ with a false-positive rate of $20 \%$ to $22 \%(17,32,33)$. Similarly in the cervical spine, facet joint pain was determined in $36 \%$ to $67 \%$ of the patients with chronic neck pain with a false-positive rate of $27 \%$ to $63 \%(18,20,28,34-39)$ with a reported prevalence of cervical discogenic pain in $16 \%$ to $20 \%$ of the patients $(39,40)$. However, while there is no data available on the thoracic spine for prevalence of discogenic pain (41), facet joints were shown to be involved in $34 \%$ to $48 \%$ of patients with chronic thoracic pain with a false-positive rate of $42 \%$ to $58 \%(18,20,42,43)$.

There is ongoing controversy regarding the validity of controlled diagnostic blocks of facet joints. In general, precision diagnostic techniques are variable in sensitivity, specificity, and accuracy. Thus, identification of false-positive rates, false-negative rates, and placebo responses is crucial. Numerous reasons have been described for false-positive responses to diagnostic anesthetic blocks, including placebo response to diagnostic injections, use of sedation, liberal use of superficial local anesthetic, and the spread of injectate to pain generating structures other than those targeted (44-46). False-positive responses may also be due to the psychological status of the patient and the effects of various drugs have been suggested to affect false-positive rates by interfering with the interpretation of the analgesic response to controlled diagnostic blocks. Further, psychological variables such as depression, anxiety, and excessive somatic symptoms are recognized as actively contributing to a patient's perception of pain (47-52). In addition, a diagnosis of depression correlates with increased pain (53-55) and anxiety decreases a patient's pain threshold and tolerance (56). In samples evaluating chronic pain patients, rates of current major depression and anxiety ranged from $15 \%$ to $59 \%$, significantly higher than the rate of $5 \%$ to $10 \%$ in persons without pain found in the general population (57-63).

Consequently, there is ongoing controversy regarding the validity of controlled diagnostic blocks. Carragee et al (64-67), and others $(44-46,68)$ have raised numerous questions about the value of controlled diagnostic blocks. Cohen and Raja (44) described that both opioids and sedatives, such as midazolam, can lead to false-positive responses by producing general analgesia and/or muscle relaxingproperties that interfere with analgesic responses of controlled diagnostic blocks. However, Manchikanti et al $(11,69,70)$ showed that psychological factors may not have significant influence on the diagnostic validity of interventional techniques in discogenic and facet joint pain. Manchikanti et al (71-74) have also shown that midazolam sedation exerts only a minimal effect on the diagnostic accuracy of controlled blocks of the cervical and lumbar facet joints in the diagnosis of facet joint pain. In addition, Manchikanti et al (75) have also demonstrated that prior exposure to opioids has no significant effect on the diagnostic validity of controlled comparative local anesthetic blocks in the diagnosis of chronic pain of spinal origin.

Consequently, the issue of providing procedural sedation in interventional pain management specifically for diagnostic techniques remains controversial. Further, there is no consensus with regards to sedation prior to controlled diagnostic blocks and the influence of sedation on the accuracy and validity of the diagnosis.

This systematic review was undertaken to review the literature to arrive at appropriate recommendations for utilization of sedation for controlled diagnostic blocks in evaluation of chronic spinal pain. 


\section{Methods}

\section{Literature Search}

A literature search included multiple databases including PubMed, EMBASE, and databases of multiple journals, Cochrane Reviews, systematic and narrative reviews, Clinical Trials Registry, cross references, and letters to the experts. A search was conducted from 1966 through November 2008.

The search terminology included interventional techniques, controlled diagnostic blocks, controlled comparative local anesthetic blocks, role of sedation for diagnostic blocks, role of opioids, role of anxiolytics, provocation discography, facet or zygapophysial joint nerve blocks.

\section{Inclusion Criteria}

Inclusion criteria concentrated on clinical relevance with types of studies concentrating on the role of sedation, anxiety on the diagnosis of spinal facet, discogenic, or sacroiliac joint pain.
Exclusion criteria included abstracts, publications in non-peer reviewed journals, technical reports, expert opinions, general review articles, and single case reports.

\section{Review Methods \\ Study Selection}

Studies were selected if they met inclusion criteria.

\section{Data Extraction}

Relevant data on methodology and outcomes were collected.

\section{Methodologic Quality Assessment}

The Agency for Healthcare Research and Quality (AHRQ) criteria for diagnostic testing (76) as reported in Table 1 were used for methodologic quality assessment. Based on the weighted scoring system developed and revised by consensus of the Guidelines Committee of the American Society of Interventional Pain Physicians

Table 1. Modified AHRQ methodologic assessment criteria for diagnostic interventions.

\begin{tabular}{|c|c|}
\hline CRITERION & $\begin{array}{c}\text { Weighted Score } \\
\text { (points) }\end{array}$ \\
\hline 1. Study Population & 15 \\
\hline \multicolumn{2}{|c|}{ - Subjects similar to populations in which the test would be used and with a similar spectrum of disease } \\
\hline 2. Adequate Description of Test & 10 \\
\hline \multicolumn{2}{|l|}{ - Details of test and its administration sufficient to allow for replication of study } \\
\hline 3. Appropriate Reference Standard & 30 \\
\hline - Appropriate reference standard (gold standard) used for comparison & 15 \\
\hline - Reference standard reproducible & 15 \\
\hline 4. Blinded Comparison of Test & 30 \\
\hline - Evaluation of test without knowledge of disease status, if possible & 15 \\
\hline - Independent, blind interpretation of test and reference & 15 \\
\hline 5. Avoidance of Verification Bias & 15 \\
\hline \multicolumn{2}{|c|}{ - Decision to perform reference standard not dependent on results of test under study } \\
\hline TOTAL SCORE & 100 \\
\hline
\end{tabular}

Adapted and modified from West et al. Systems to Rate the Strength of Scientific Evidence, Evidence Report, Technology Assessment No. 47. AHRQ Publication No. 02-E016 (76). 
(ASIPP) (12), a total of 100 total points may be awarded for each study. This system has been employed in other systematic reviews $(41,42)$. Only studies scoring 50 or above were used in the analysis. Each study was scored independently by 2 reviewers. Any discrepancies or conflicts were arbitrated by a third author to reach a consensus agreement. Any disagreement among the reviewers was resolved by discussion and consensus. If there was a conflict of interest with the reviewed manuscript with authorship or any other type of conflict, the involved authors did not review the manuscript for quality assessment or evidence synthesis.

\section{Qualitative Analysis of Evidence}

Qualitative analysis was conducted using 5 levels of evidence, ranging from Level I to III with 3 subcategories in Level II, as illustrated in Table 2 (77).

\section{Results}

\section{Literature Search \\ Methodologic Quality Assessment}

Figure 1 illustrates the search results. The search yielded 107 articles for review, of these, only 6 were relevant to the study question, with 2 studies evaluating role of sedation for non-specific intervention techniques $(78,79)$, and 4 studies evaluating the role of sedation for diagnostic interventional techniques (7174). Methodologic quality assessment of the 6 relevant studies (71-73) met the inclusion criteria for methodologic quality assessment. Two studies $(78,79)$ were not included as they were not related specifically to diagnostic interventions and also the role of sedation and its influence on diagnostic value and validity was not evaluated. Further, one study (74) was the evaluation of the role of placebo and nocebo effects of perioperative administration of sedatives and opioids in in- terventional pain management on the data obtained from the previous controlled studies (71-73).

Table 3 illustrates the methodologic quality assessment of studies evaluating the effect of sedation. There were no studies available evaluating the influence of sedation on diagnostic value or validity of either discogenic pain or sacroiliac joint pain.

\section{Study Methods}

In 2 studies $(71,72)$, there were 60 patients in each group. In the third study (73) there were 20 patients in each group. Each patient, based on the randomization, received 1 of the 3 solutions in incremental doses of $1 \mathrm{~mL}$ with a maximum of $5 \mathrm{~mL}$ in all groups; $5 \mathrm{~mL}$ of $\mathrm{NaCl}$ in Group I, $1 \mathrm{mg}$ of midazolam per $\mathrm{mL}$ ( $5 \mathrm{mg}$ per $5 \mathrm{~mL}$ ) in Group II, or $50 \mathrm{mcg}$ of fentanyl per $\mathrm{mL}$ (250 mcg per $5 \mathrm{~mL}$ ) in Group III. Patient and investigator were blinded to the allocation sequence, as well as the solution administered, in all cases. The solutions were administered slowly based on the patient's response with relaxation and/or a feeling of drowsiness or until the entire syringe of $5 \mathrm{~mL}$ was administered. Once the patients expressed either drowsiness or relaxation or the maximum dose was administered, assessment of pain on a numeric pain scale and the ability to perform pre-sedation painful movements were reassessed. After completion of the evaluation, unblinding was carried out and the amount of sedation administered in Groups II and III were noted on the record.

\section{Outcomes Assessment}

In all studies, the outcomes were assessed at baseline prior to the administration of the solution and after the administration of the solution. Multiple parameters included numeric pain scale, percent of pain relief, and ability to perform prior painful movements.

Table 2. Modified quality of evidence developed by AHRQ.

\begin{tabular}{|l|l|}
\hline I: & Evidence obtained from at least one properly randomized controlled trial or multiple well-conducted diagnostic studies \\
\hline II-1: & $\begin{array}{l}\text { Evidence obtained from well-designed controlled trials without randomization or at least one well-controlled diagnostic study of } \\
\text { adequate size }\end{array}$ \\
\hline II-2: & $\begin{array}{l}\text { Evidence obtained from well-designed cohort or case-control analytic studies, preferably from more than one center or research } \\
\text { group or evidence obtained from at least one properly designed small diagnostic accuracy study }\end{array}$ \\
\hline II-3: & $\begin{array}{l}\text { Evidence obtained from multiple time series with or without the intervention. Dramatic results in uncontrolled experiments } \\
\text { (such as the results of the introduction of penicillin treatment in the 1940s) could also be regarded as this type of evidence }\end{array}$ \\
\hline III: & Opinions of respected authorities, based on clinical experience descriptive studies and case reports or reports of expert committees \\
\hline
\end{tabular}

Adapted from the U.S. Preventive Services Task Force (USPSTF) (77). 


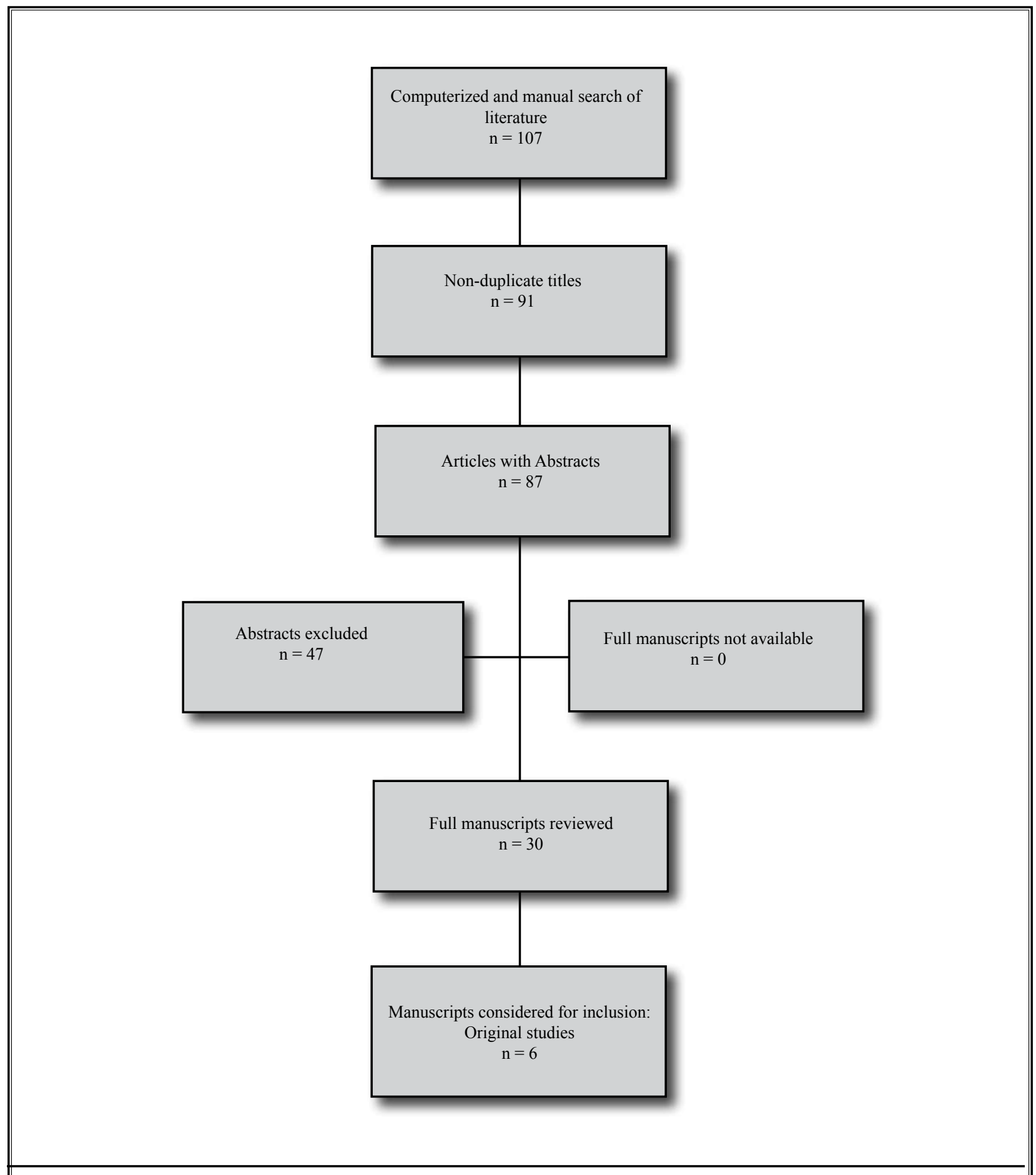

Fig. 1. The flow diagram of the selection process of the literature. 
Table 3. Methodologic quality assessment and scoring

\begin{tabular}{|c|c|c|c|c|c|c|c|c|}
\hline \multirow[b]{2}{*}{ Study } & \multirow[b]{2}{*}{$\begin{array}{c}1 . \\
\text { Study } \\
\text { Population } \\
\text { (15) }\end{array}$} & \multirow[b]{2}{*}{$\begin{array}{c}2 . \\
\text { Adequate } \\
\text { Description } \\
\text { of Test } \\
\text { (10) }\end{array}$} & \multicolumn{2}{|c|}{$\begin{array}{c}3 . \\
\text { Appropriate Reference } \\
\text { Standard } \\
(\mathbf{3 0}) \\
\end{array}$} & \multicolumn{2}{|c|}{$\begin{array}{c}4 . \\
\text { Blinded Comparison of } \\
\text { Test } \\
(\mathbf{3 0}) \\
\end{array}$} & \multirow[b]{2}{*}{$\begin{array}{c}5 . \\
\text { Avoidance } \\
\text { of } \\
\text { Verification } \\
\text { Bias } \\
\text { (15) }\end{array}$} & \multirow[b]{2}{*}{$\begin{array}{c}\text { TOTAL } \\
(\mathbf{1 0 0})\end{array}$} \\
\hline & & & $\begin{array}{c}\text { Appropriate } \\
\text { reference } \\
\text { standard } \\
\text { (gold } \\
\text { standard) } \\
\text { used for } \\
\text { comparison } \\
\text { (15) }\end{array}$ & $\begin{array}{c}\text { Reference } \\
\text { standard } \\
\text { reproducible } \\
(15)\end{array}$ & $\begin{array}{c}\text { Evaluation } \\
\text { of test } \\
\text { without } \\
\text { knowledge } \\
\text { of disease } \\
\text { status, if } \\
\text { possible } \\
\text { (15) }\end{array}$ & $\begin{array}{c}\text { Independent, } \\
\text { blind } \\
\text { interpretation } \\
\text { of test and } \\
\text { reference } \\
\text { (15) }\end{array}$ & & \\
\hline $\begin{array}{l}\text { Manchikanti et al } \\
2004(72)\end{array}$ & 15 & 0 & - & 15 & - & 15 & 15 & 70 \\
\hline $\begin{array}{l}\text { Manchikanti et al } \\
2004 \text { (71) }\end{array}$ & 15 & 0 & - & 15 & - & 15 & 15 & 70 \\
\hline $\begin{array}{l}\text { Manchikanti et al } \\
2006 \text { (73) }\end{array}$ & 15 & 0 & - & 15 & - & 15 & 15 & 70 \\
\hline
\end{tabular}

( ) weighted item score

Methodological criteria and scoring adapted from West et al. Systems to Rate the Strength of Scientific Evidence, Evidence Report, Technology Assessment No. 47. AHRQ Publication No. 02-E016 (76).

\section{Descriptive Characteristics}

Descriptive characteristics of these 3 studies are included in Table 4. All 3 studies (71-73) were performed by the same group utilizing the same methodology. Manchikanti et al (71) performed a randomized, placebo-controlled, double-blind study and demonstrated that $2 \%$ of the patients in Group I (placebo group - $\mathrm{NaCl}$ solution), $5 \%$ in Group II (midazolam group), and $7 \%$ in Group III (fentanyl group) had experienced $\geq 80 \%$ pain relief and were able to perform baseline painful movements in the post follow-up period in patients with chronic low back pain of lumbar facet joint origin. Further, evaluation of significant relief of $\geq 50 \%$ relief with ability to perform baseline painful movements in the post follow-up period was seen in $7 \%, 5 \%$, and $13 \%$ of the patients in Groups I, II, and III. Significant differences were only noted with regards to the relaxation status with $40 \%$ in Group I, $93 \%$ in Group II, and $87 \%$ in Group III. This study showed no significant differences between the pain relief and ability to perform painful movements in any of the groups.

Manchikanti et al (72) performed a randomized, prospective, double-blind, placebo-controlled evaluation on the effect of sedation in the diagnostic validity of cervical facet joint pain. Pain relief of $\geq 80 \%$ was noted in $5 \%$ of the patients in Group I, $8 \%$ in Group II, and $8 \%$ in Group III. However, pain relief of $\geq 50 \%$ was noted in $8 \%$ of the patients in Group I, $13 \%$ in Group II, and $27 \%$ in Group II. (72).

In the study by Manchikanti et al (73), 50\% to $100 \%$ of the patients reported relaxation, and as many as $10 \%$ of the patients experienced significant pain relief ( $80 \%$ or greater) and were able to perform movements that were painful prior to the administration of intravenous sodium chloride, midazolam, or fentanyl. There were no significant differences noted either among the groups or between regions (cervical vs. lumbar). Significant differences were noted only with regards to relaxation status, with $50 \%$ reported in Group I and $100 \%$ in Groups II and III. Thus, overall this study showed no significant differences in any of the groups between pain relief or the ability to perform painful movements and the type of sedation.

Based on the results of a randomized, placebocontrolled evaluation, $13 \%$ to $30 \%$ of all the patients receiving either sodium chloride solution, midazolam, or fentanyl reported a placebo response (74). A small proportion ( $3 \%$ to $8 \%$ ) of patients also reported a nocebo response, where they felt worse. The majority of the patients $(67 \%$ to $79 \%)$ described no significant change from their previous experience. It is con- 
Table 4. Descriptive characteristics of sedation for interventional techniques.

\begin{tabular}{|c|c|c|c|c|c|}
\hline Study/Methods & Participants & Intervention(s) & Outcome(s) & Result(s) & Conclusion(s) \\
\hline $\begin{array}{l}\text { Manchikanti et al } \\
\text { (72) } 2004 \\
\text { Randomized, } \\
\text { double-blind }\end{array}$ & $\begin{array}{l}180 \text { patients } \\
\text { with cervical } \\
\text { facet joint } \\
\text { pain }\end{array}$ & $\begin{array}{l}\text { Randomization } \\
\text { into } 3 \text { equal groups } \\
\text { (60/group); titration } \\
\text { of agent } 1 \mathrm{~mL} \text { at } \\
\text { a time; relaxed or } \\
5 \mathrm{~mL} \text { max given. } \\
\text { Group I - NaCl } \\
\text { Group II } \\
\text { - midazolam } \\
\text { Group III - fentanyl }\end{array}$ & $\begin{array}{l}80 \% \text { pain } \\
\text { relief and } \\
\text { ability to } \\
\text { perform } \\
\text { previously } \\
\text { painful } \\
\text { movements }\end{array}$ & $\begin{array}{l}\text { Pain relief of }>80 \% \\
\text { was noted in } 5 \% \text { of the } \\
\text { patients in Group I, } 8 \% \\
\text { in Group II, and } 8 \% \text { in } \\
\text { Group III. However, > } \\
50 \% \text { relief was noted } \\
\text { in } 8 \% \text { of the patients } \\
\text { in Group I, } 13 \% \text { of the } \\
\text { patients in Group II, } \\
\text { and } 27 \% \text { of the patients } \\
\text { in Group III. Overall, } \\
8 \% \text { of the patients in } \\
\text { Group I, 13\% in Group } \\
\text { II, and } 27 \% \text { in Group } \\
\text { III were able to perform } \\
\text { movements which were } \\
\text { painful prior to injection. }\end{array}$ & $\begin{array}{l}\text { The administration of sedation } \\
\text { with midazolam or fentanyl is a } \\
\text { confounding factor in the diagnosis } \\
\text { of cervical facet joint pain in } \\
\text { patients with chronic neck pain. } \\
\text { However, if }>80 \% \text { pain relief } \\
\text { with the ability to perform prior } \\
\text { painful movements is used as the } \\
\text { standard for evaluating the effect of } \\
\text { controlled local anesthetic blocks, } \\
\text { the diagnostic validity of cervical } \\
\text { facet joint nerve blocks may be } \\
\text { preserved. }\end{array}$ \\
\hline $\begin{array}{l}\text { Manchikanti et al } \\
\text { (71) } 2004 \\
\text { Randomized, } \\
\text { double-blind }\end{array}$ & $\begin{array}{l}180 \text { patients } \\
\text { with lumbar } \\
\text { facet joint } \\
\text { pain }\end{array}$ & $\begin{array}{l}\text { Randomization } \\
\text { into } 3 \text { equal groups } \\
\text { (60/group); titration } \\
\text { of agent } 1 \mathrm{~mL} \text { at a } \\
\text { time; relaxed or } 5 \\
\text { mL max given } \\
\text { Group I - } \mathrm{NaCl} \\
\text { Group II } \\
\text { - midazolam } \\
\text { Group III - fentanyl }\end{array}$ & $\begin{array}{l}80 \% \text { pain } \\
\text { relief and } \\
\text { ability to } \\
\text { perform } \\
\text { previously } \\
\text { painful } \\
\text { movements }\end{array}$ & $\begin{array}{l}\text { Pain relief of }>80 \% \\
\text { was noted in } 2 \% \text { of the } \\
\text { patients in Group I, 5\% } \\
\text { of the patients in Group } \\
\text { II, and } 7 \% \text { in Group } \\
\text { III. Pain relief of }>50 \% \\
\text { was noted in } 7 \% \text { of the } \\
\text { patients in Group I, 5\% of } \\
\text { the patients in Group II, } \\
\text { and } 13 \% \text { of the patients } \\
\text { in Group III. There were } \\
\text { no significant differences } \\
\text { among the groups. }\end{array}$ & $\begin{array}{l}\text { The administration of sedation } \\
\text { with midazolam or fentanyl is a } \\
\text { confounding factor in the diagnosis } \\
\text { of lumbar facet joint pain in } \\
\text { patients with chronic low back } \\
\text { pain. However, this study suggests } \\
\text { that if strict criteria including pain } \\
\text { relief and the ability to perform } \\
\text { prior painful movements is used } \\
\text { as the standard for evaluating the } \\
\text { effect of controlled local anesthetic } \\
\text { blocks, the diagnostic validity of } \\
\text { lumbar facet joint nerve blocks may } \\
\text { be preserved. }\end{array}$ \\
\hline $\begin{array}{l}\text { Manchikanti et al } \\
\text { (73) } 2006 \\
\text { Randomized, } \\
\text { double-blind }\end{array}$ & $\begin{array}{l}60 \text { patients } \\
\text { with } \\
\text { combined } \\
\text { cervical facet } \\
\text { joint pain and } \\
\text { lumbar facet } \\
\text { joint pain }\end{array}$ & $\begin{array}{l}\text { Randomization } \\
\text { into } 3 \text { equal groups } \\
\text { (20/group); titration } \\
\text { of agent } 1 \mathrm{~mL} \text { at a } \\
\text { time; relaxed or } 5 \\
\text { mL max given } \\
\text { Group I - NaCl } \\
\text { Group II } \\
\text { - midazolam } \\
\text { Group III - fentanyl }\end{array}$ & $\begin{array}{l}80 \% \text { pain } \\
\text { relief and } \\
\text { ability to } \\
\text { perform } \\
\text { previously } \\
\text { painful } \\
\text { movements }\end{array}$ & $\begin{array}{l}\text { Overall, } 50 \% \text { of the } \\
\text { patients were relaxed or } \\
\text { sedated in the placebo } \\
\text { group, while } 100 \% \\
\text { of the patients in the } \\
\text { midazolam and fentanyl } \\
\text { groups were relaxed or } \\
\text { sedated. As many as } 10 \% \\
\text { of the patients reported } \\
\text { significant relief } \\
(\geq 80 \%) \text { with the ability } \\
\text { to perform prior painful } \\
\text { movements. }\end{array}$ & $\begin{array}{l}\text { Perioperative administration of } \\
\text { sodium chloride, midazolam, or } \\
\text { fentanyl can confound results in } \\
\text { the diagnosis of combined cervical } \\
\text { and lumbar facet joint pain. False- } \\
\text { positive results with placebo or } \\
\text { sedation may be seen in a small } \\
\text { proportion of patients. }\end{array}$ \\
\hline
\end{tabular}

cluded that sodium chloride, midazolam, and fentanyl are capable of producing placebo, as well as nocebo, responses in patients undergoing interventional procedures. In designing research and interpreting outcomes, placebo and nocebo effects must be taken into consideration.

In all the studies (71-73), Manchikanti et al concluded that prudent administration of intravenous preoperative sedative dose of a narcotic such as fentanyl or an anxiolytic such as midazolam is no more likely to cause a small proportion of patients to report false-positive pain relief with active motion testing than sodium chloride placebo. These studies suggested that the prudent administration of midazolam and fentanyl to patients who are not relaxed may not have any significant adverse effect on the diagnostic valid- 
ity of controlled comparative local anesthetic blocks in the cervical or lumbar spine.

Finally, the previous exposure to the study drugs has been shown not to have any significant effect on the response during diagnostic blockade (75).

\section{Level of Evidence}

Based on the 3 studies (71-73) evaluating the influence of sedation on the diagnostic accuracy in the diagnosis of facet joint pain, based on United States Preventive Services Task Force (USPSTF) criteria (77), as shown in Table 2 criteria, the indicated evidence is Level II-1, in the evaluation of cervical and lumbar facet joint pain.

\section{Discussion}

Based on the comprehensive evaluation of all the available literature, the lack of influence of sedation on controlled facet joint nerve blocks on the diagnosis of cervical and lumbar facet joint pain, the indicated evidence is Level II-1. All of the studies showed a lack of influence of sedation either with midazolam or even with fentanyl with criterion standard of $80 \%$ pain relief and the ability to perform previously painful movements. The false-positive results were obtained in $7 \%$ of the patients with lumbar facet joint nerve blocks in Group III receiving fentanyl, whereas it was $8 \%$ in patients with cervical facet joint pain. However, the authors have cautioned that with an application of $50 \%$ pain relief as the criterion standard, this proportion will increase to $13 \%$ with lumbar facet joint nerve blocks, whereas it would increase to $27 \%$ in the cervical group. Based on the results of this systematic review it is postulated that appropriate administration of sedation either with midazolam or with fentanyl will not adversely affect the diagnostic validity of diagnostic facet joint nerve blocks either in the cervical spine or lumbar spine. However, $80 \%$ pain relief with the ability to perform previously painful movements should be used as a criterion standard. Any other standard is not applicable.

This systematic review showed a significant paucity of literature and multiple methodological challenges in assessing the influence of sedation on diagnostic interventional techniques. We were able to find only 3 manuscripts (71-73) by the same authors evaluating either cervical and/or lumbar facet joint pain. There were no studies evaluating provocation discography or sacroiliac joint blocks. Further, this evaluation has not included patients with combined midazolam and fentanyl. Based on the present systematic review, it appears that a significant proportion of patients may require sedation during the perioperative period of diagnostic interventional techniques (78-80).

In fact, Cucuzzella et al (78) performed a survey of 500 consecutive patients receiving lumbar, thoracic, and/or cervical spinal injections. A 12-item questionnaire assessing patients' perceived anxiety was administered before a spinal injection. Subjects were also given the questionnaire after their primal injection. Percentages requesting sedation for a first and potential second procedure were assessed. Additionally, anxiety level and pain rating, location of injection, age, sex, and other medication use were analyzed to determine the effect on the request for sedation. Seventeen percent of patients questioned requested sedation before an injection and $28 \%$ would request sedation if they were to have a second injection. Cucuzzella and colleagues (78) concluded that routine sedation before diagnostic and therapeutic injections is not necessary as the majority of patients would not request sedation before the procedure when given the option. However, in some patients sedation is indicated, and many patients may benefit from educational material on sedation before the injection.

In another study from the same institution, Kim et al (79) conducted a study with 301 consecutive spinal injection patients given a choice to take oral or IV diazepam, or no sedation before a spinal injection. All participating patients filled in a validated anxiety questionnaire before the injection. Patients were asked after the injection whether they were satisfied with their decision regarding sedation and whether their anxiety was controlled effectively. One hundred fifty-seven patients (58\%) chose to have IV sedation. Of those, $141(90 \%)$ indicated that their anxiety was controlled. Eleven (7\%) did not think that their anxiety was controlled and 5 (3\%) did not provide a response.

As eluded by Manchikanti and Giordano (80), Kim et al (79) showed that $58 \%$ of the patients initially chose to be sedated and this number increased after the first intervention. However, in their previous study by Cucuzzella et al (78) only $17 \%$ of the patients requested sedation initially reflecting a wide variance. Consequently, it is important to consider the differences in the physical and psychological characteristics of patients as seen by interventional physiatrists and interventional pain physicians. 
Multiple drugs utilized for anxiolysis and analgesia during interventional procedures include benzodiazepines, opioids, and other agents (81). Midazolam and fentanyl are more frequently used intervenous drugs for intraoperative sedation and analgesia due to the expected short duration of action combined with rapid onset of action. Midazolam is a short-acting benzodiazepine affecting the central nervous system depressant activities. The effects of midazolam on the central nervous system are dependent on the dose administered, the route of administration, and the presence or absence of other medications. Clinical experience has shown midazolam to be 3 to 4 times as potent per mg as diazepam.

Fentanyl is a narcotic analgesic. A dose of 100 $\mathrm{mcg}$ or $0.1 \mathrm{mg}$ or $2 \mathrm{~mL}$ is approximately equivalent in analgesic activity to $10 \mathrm{mg}$ of morphine or $75 \mathrm{mg}$ of meperidine. The principle actions of therapeutic value are analgesia and sedation. The onset of action of fentanyl is almost immediate when the drug is given intravenously.

The present evaluation may be criticized for several potential drawbacks of the included studies (71-73). However, all the studies were placebo-controlled, randomized, double-blind, with 60 patients in the smallest group in 3 groups in 2 studies $(71,72)$, with appropriate evaluation of outcome parameters of pain relief and the ability to perform prior painful movements. The question about an additional group with midazolam and fentanyl may be legitimate. However, administration of the 2 drugs in a safe manner would have been extremely difficult, specifically limiting the total dosage to $5 \mathrm{~mL}$ with $50 \%$ midazolam and $50 \%$ fentanyl. The drugs cannot be mixed reliably and uniformly. Further, they may have to be provided in 2 separate syringes. In such a scenario, the study would not be blind. Thus, the authors explained that the combined effect of midazolam with fentanyl was not evaluated.
This systematic review utilized stringent criteria for inclusion. In the evidence synthesis, we attempted to evaluate all types of diagnostic studies, however only limited data was available. Further, since the publication of this literature, Manchikanti et al (75) have illustrated a significant lack of influence of prior exposure on the diagnostic validity of controlled facet joint injections. Even then, it is prudent to conduct multiple studies not only evaluating the role of sedation in diagnosing facet joint pain, but also in the diagnosis of discogenic and sacroiliac joint pain and all other types of diagnostic interventions. Consequently, the limitations of this manuscript include the paucity of the data in general and the lack of availability of data in evaluation of the influence of sedation, with or without opioids, in the diagnosis of discogenic pain and sacroiliac joint pain.

\section{Conclusion}

This systematic review provides no significant evidence of the influence of sedation either with midazolam or fentanyl in the evaluation of cervical and lumbar facet joint pain with controlled cervical and lumbar facet joint nerve blocks with indicated evidence of Level II-1. However, the results of this systematic review only apply for cervical and lumbar facet joint blocks under sedation utilizing the criterion standard of $80 \%$ pain relief with controlled comparative local anesthetic blocks with the ability to perform prior painful movements by the patient immediately.

\section{Acknowledgments}

The authors wish to thank the editorial board of Pain Physician for review and criticism in improving the manuscript; Sekar Edem for assistance in search of literature; and Tonie M. Hatton and Diane E. Neihoff, transcriptionists (Pain Management Center of Paducah), for their assistance in preparation of this manuscript. 


\section{References}

1. Manchikanti L, Boswell MV. Interventional techniques in ambulatory surgical centers: A look at the new payment system. Pain Physician 2007; 10:627650.

2. Manchikanti L, Giordano J. Physician payment 2008 for interventionalists: Current state of health care policy. Pain Physician 2007; 10:607-626.

3. Manchikanti L, Hirsch JA. Issues in health care: Interventional pain management at the crossroads. Pain Physician 2007; 10:261-284.

4. Manchikanti L, Pampati V, Hirsch J. Analysis of growth of interventional techniques in managing chronic pain in Medicare population: A 10-year evaluation from 1997 to 2006. Pain Physician 2009; 12:9-34.

5. Specialty Utilization data files from CMS: www.cms.hhs.gov/

6. Boswell MV, Trescot AM, Datta S, Schultz DM, Hansen HC, Abdi S, Sehgal N, Shah RV, Singh V, Benyamin RM, Patel VB, Buenaventura RM, Colson JD, Cordner HJ, Epter RS, Jasper JF, Dunbar EE, Atluri SL, Bowman RC, Deer TR, Swicegood JR, Staats PS, Smith HS, Burton AW, Kloth DS, Giordano J, Manchikanti L. Interventional techniques: Evidencebased practice guidelines in the management of chronic spinal pain. Pain Physician 2007; 10:7-111.

7. Boswell MV, Colson JD, Sehgal N, Dunbar EE, Epter R. A systematic review of therapeutic facet joint interventions in chronic spinal pain. Pain Physician 2007; 10:229-253.

8. Sehgal N, Dunbar EE, Shah RV, Colson JD. Systematic review of diagnostic utility of facet (zygapophysial) joint injections in chronic spinal pain: An update. Pain Physician 2007; 10:213-228.

9. Manchikanti L, Singh A. Therapeutic opioids: A ten-year perspective on the complexities and complications of the escalating use, abuse, and nonmedical use of opioids. Pain Physician 2008; 11: S63-S88.

10. Trescot AM, Helm $S$, Hansen $H$, Benyamin R, Glaser SE, Adlaka R, Patel S, Manchikanti L. Opioids in the management of chronic non-cancer pain: An update of American Society of the Interventional Pain Physicians' (ASIPP) guidelines. Pain Physician 2008; 11:S5S62.

11. Manchikanti L, Cash KA, Pampati V, Fellows B. Influence of psychological vari- ables on the diagnosis of facet joint involvement in chronic spinal pain. Pain Physician 2008; 11:145-160.

12. Manchikanti L, Singh V, Derby R, Schultz DM, Benyamin RM, Prager JP, Hirsch JA. Reassessment of evidence synthesis of occupational medicine practice guidelines for interventional pain management. Pain Physician 2008; 11:393482.

13. Bogduk N. International spinal injection society guidelines for the performance of spinal injection procedures. Part 1: Zygapophyseal joint blocks. Clin J Pain 1997; 13:285-302.

14. Hancock MJ, Maher CG, Latimer J, Spindler MF, McAuley JH, Laslett M, Bogduk $\mathrm{N}$. Systematic review of tests to identify the disc, SIJ or facet joint as the source of low back pain. Eur Spine J 2007; 10:1539-1550.

15. Buenaventura RM, Shah RV, Patel V, Benyamin R, Singh V. Systematic review of discography as a diagnostic test for spinal pain: An update. Pain Physician 2007; 10:147-164.

16. Hansen HC, McKenzie-Brown AM, Cohen SP, Swicegood JR, Colson JD, Manchikanti L. Sacroiliac joint interventions: A systematic review. Pain Physician 2007; 10:165-184.

17. Manchikanti L, Singh V, Pampati V, Damron K, Barnhill R, Beyer C, Cash K. Evaluation of the relative contributions of various structures in chronic low back pain. Pain Physician 2001; 4:308316.

18. Manchukonda R, Manchikanti KN, Cash KA, Pampati V, Manchikanti L. Facet joint pain in chronic spinal pain: An evaluation of prevalence and false-positive rate of diagnostic blocks. J Spinal Disord Tech 2007; 20:539-545.

19. Manchikanti L, Manchukonda R, Pampati V, Damron KS, McManus CD. Prevalence of facet joint pain in chronic low back pain in postsurgical patients by controlled comparative local anesthetic blocks. Arch Phys Med Rehabil 2007; 88:449-455.

20. Manchikanti L, Boswell MV, Singh V, Pampati V, Damron KS, Beyer CD. Prevalence of facet joint pain in chronic spinal pain of cervical, thoracic, and lumbar regions. BMC Musculoskelet Disord 2004; 5:15.

21. Schwarzer AC, Aprill CN, Derby R, Fortin J, Kine G, Bogduk N. Clinical features of patients with pain stemming from the lumbar zygapophysial joints. Is the lumbar facet syndrome a clinical entity? Spine 1994; 19:1132-1137.

22. Schwarzer AC, Aprill CN, Derby R, Fortin $J$, Kine G, Bogduk N. The relative contributions of the disc and zygapophyseal joint in chronic low back pain. Spine 1994; 19:801-806.

23. Manchikanti L, Pampati V, Fellows B, Bakhit CE. The diagnostic validity and therapeutic value of lumbar facet joint nerve blocks with or without adjuvant agents. Curr Rev Pain 2000; 4:337344.

24. Manchikanti L, Pampati V, Fellows B, Bakhit C. Prevalence of lumbar facet joint pain in chronic low back pain. Pain Physician 1999; 2:59-64.

25. Manchikanti L, Pampati V, Fellows B, Baha AG. The inability of the clinical picture to characterize pain from facet joints. Pain Physician 2000; 3:158-166.

26. Manchikanti L, Hirsch JA, Pampati V. Chronic low back pain of facet (zygapophysial) joint origin: Is there a difference based on involvement of single or multiple spinal regions? Pain Physician 2003; 6:399-405.

27. Manchikanti L, Manchikanti K, Cash KA, Singh V, Giordano J. Age-related prevalence of facet joint involvement in chronic neck and low back pain. Pain Physician 2008; 11:67-75.

28. Manchikanti L, Singh V, Pampati V, Damron KS, Beyer CD, Barnhill RC. Is there correlation of facet joint pain in lumbar and cervical spine? An evaluation of prevalence in combined chronic low back and neck pain. Pain Physician 2002; 5:365-371.

29. Schwarzer AC, Aprill CN, Derby R, Fortin J, Kine G, Bogduk N. The false-positive rate of uncontrolled diagnostic blocks of the lumbar zygapophysial joints. Pain 1994; 58:195-200.

30. Schwarzer AC, Aprill CN, Derby R, Fortin J, Kine G, Bogduk N. The prevalence and clinical features of internal disc disruption in patients with chronic low back pain. Spine 1995; 20:1878-1883.

31. Wolfer L, Derby R, Lee JE, Lee SH. Systematic review of lumbar provocation discography in asymptomatic subjects with a meta-analysis of false-positive rates. Pain Physician 2008; 11:513538.

32. Maigne JY, Aiviliklis A, Pfefer F. Results of sacroiliac joint double block and value of sacroiliac pain provocation test in 
54 patients with low back pain. Spine 1996; 21:1889-1892.

33. Irwin RW, Watson T, Minick RP, Ambrosius WT. Age, body mass index, and gender differences in sacroiliac joint pathology. Am J Phys Med Rehabil 2007; 86:37-44.

34. Lord SM, Barnsley L, Wallis BJ, Bogduk N. Chronic cervical zygapophysial joint pain with whiplash: A placebo-controlled prevalence study. Spine 1996; 21:1737-1745.

35. Manchikanti L, Manchikanti KN, Pampati $\mathrm{V}$, Brandon DE, Giordano J. The prevalence of facet-joint-related chronic neck pain in postsurgical and nonpostsurgical patients: A comparative evaluation. Pain Pract 2008; 8:5-10.

36. Barnsley L, Lord SM, Wallis BJ, Bogduk $\mathrm{N}$. The prevalence of chronic cervical zygapophyseal joint pain after whiplash. Spine 1995; 20:20-26.

37. Manchikanti L, Singh V, Rivera J, Pampati V. Prevalence of cervical facet joint pain in chronic neck pain. Pain Physician 2002; 5:243-249.

38. Speldewinde GC, Bashford GM, Davidson IR. Diagnostic cervical zygapophyseal joint blocks for chronic cervical pain. Med J Aust 2001; 174:174-176.

39. Yin W, Bogduk N. The nature of neck pain in a private pain clinic in the United States. Pain Med 2008; 9:196-203.

40. Bogduk N, Aprill C. On the nature of neck pain, discography and cervical zygapophysial joint blocks. Pain 1993; 54:213-217.

41. Singh V, Manchikanti L, Shah RV, Dunbar EE, Glaser SE. Systematic review of thoracic discography as a diagnostic test for chronic spinal pain. Pain Physician 2008; 11:631-642.

42. Atluri S, Datta S, Falco FJ, Lee M. Systematic review of diagnostic utility and therapeutic effectiveness of thoracic facet joint interventions. Pain Physician 2008; 11:611-629.

43. Manchikanti L, Singh V, Pampati V, Beyer C, Damron K. Evaluation of the prevalence of facet joint pain in chronic thoracic pain. Pain Physician 2002; 5:354359.

44. Cohen SP, Raja SN. Pathogenesis, diagnosis and treatment of lumbar zygapophysial (facet) joint pain. Anesthesiology 2007; 106:591-614.

45. Hogan QH, Abram SE. Neural blockade for diagnosis and prognosis: A review. Anesthesiology 1997; 86:216-241.
46. Cohen SP, Larkin T, Chang A, Stojanovic MP. The causes of false-positive medial branch blocks in soldiers and retirees. Mil Med 2004; 169:781-786.

47. Aronoff GM, Tota-Faucette M, Phillips $\mathrm{L}$, Lawrence CN. Are pain disorder and somatization disorder valid diagnostic entities. Curr Rev Pain 2000; 4:309312.

48. Bacon NM, Bacon SF, Atkinson JH, Slater MA, Patterson TL, Grant I, Garfin SR. Somatization symptoms in chronic low back pain patients. Psychosom Med 1994; 56:118-127.

49. Fishbain DA. Somatization, secondary gain, and chronic pain: Is there a relationship? Curr Rev Pain 1998; 6:101108.

50. Korbon GA, DeGood DE, Schroeder ME, Slater MA, Patterson TL, Grant I, Garfin SR. The development of a somatic amplication rating scale for low back pain. Spine 1987; 12:787-791.

51. Sikorski JM, Stampfer HG, Cole RM, Wheatley AE. Psychological aspects of chronic low back pain. Aust N Z J Surg 1966; 66:294-297.

52. Tollison CD, Satterthwaite JR. Chronic benign pain: Diagnosis and behavioral management. J Musculoskeletal Med 1991; 8:55-66.

53. Bair MJ, Robinson RL, Katon W, Kroenke K. Depression and pain comorbidity: A literature review. Arch Intern Med 2003; 163:2433-2445.

54. Epker J, Block AR. Presurgical psychological screening in back pain patients: A review. Clin J Pain 2001; 17:200-205.

55. Burns J, Johnson B, Mahoney N, Devine J, Pawl R. Cognitive and physical capacity process variables predict longterm outcome after treatment of chronic pain. J Clin Consult Psychiatry 1998; 66:434-439.

56. Davis PJ, Reeves JL, Hastie BA, GraffRadford SB, Naliboff BD. Depression determines illness conviction and pain impact: A structural equation modeling analysis. Pain Med 2000; 1:238-246.

57. Rivera JJ, Singh V, Fellows B, Pampati V, Damron KS, McManus CD. Reliability of psychological evaluation in chronic pain in an interventional pain management setting. Pain Physician 2005; 8:375-383.

58. Manchikanti L, Fellows B, Pampati V, Damron KS, Beyer CD, Barnhill RC. Comparison of psychological status of chronic pain patients with general pop- ulation. Pain Physician 2002; 5:40-48.

59. Manchikanti L, Pampati V, Beyer CD, Damron KS. Do number of pain conditions influence emotional status? Pain Physician 2002; 5:200-205.

60. Manchikanti L, Pampati VS, Damron KS, Beyer CD, Barnhill RC. Evaluation of psychological status in chronic low back pain: Comparison with general population. Pain Physician 2002; 5:149-155.

61. Manchikanti L, Pampati V, Fellows B, Beyer CD, Damron KS, Barnhill RC, Burks TA. Characteristics of chronic low back pain in patients in an interventional pain management setting: $A$ prospective evaluation. Pain Physician 2001; 4:131-142.

62. Rush AJ, Polatin P, Gatchel RJ. Depression and chronic low back pain. Spine 2000; 25:2566-2571.

63. Dersh J, Mayer T, Theodore BR, Polatin P, Gatchel RJ. Do psychiatric disorders first appear preinjury or postinjury in chronic disabling occupational spinal disorders? Spine 2007; 32:1045-1051.

64. Carragee EJ, Haldeman S, Hurwtiz E. The pyrite standard: The Midas touch in the diagnosis of axial pain syndromes. Spine J 2007; 7:27-31.

65. Carragee EJ. Is lumbar discography a determinate of discogenic low back pain: Provocative discography reconsidered. Curr Rev Pain 2000; 4:301308.

66. Carragee EJ, Chen Y, Tanner CM, Truong T, Lau E, Brito JL. Provocative discography in patients after limited lumbar discectomy: A controlled, randomized study of pain response in symptomatic and asymptomatic subjects. Spine 2000; 25:3065-3071.

67. Carragee EJ, Tanner CM, Khurana S, Hayward C, Welsh J, Date E, Truong T, Rossi M, Hagle $C$. The rates of falsepositive lumbar discography in select patients without low back symptoms. Spine 2000; 25:1373-1381.

68. Cohen SP, Mullings R, Abdi S. The pharmacologic treatment of muscle pain. Anesthesiology 2004; 101:495-526.

69. Manchikanti L, Singh V, Pampati VS, Fellows B, Beyer C, Damron K, Cash KA. Provocative discography in low back pain patients with or without somatization disorder: A randomized prospective evaluation. Pain Physician 2001; 4:227-239.

70. Manchikanti L, Pampati V, Fellows B, 
Rivera JJ, Damron KS, Beyer CD, Cash $\mathrm{KA}$. Influence of psychological factors on the ability to diagnose chronic low back pain of facet joint origin. Pain Physician 2001; 4:349-357.

71. Manchikanti L, Damron KS, Rivera J, McManus CD, Jackson SD, Barnhill RC, Martin JC. Evaluation of effect of sedation as a confounding factor in the diagnostic validity of lumbar facet joint pain: A prospective, randomized, double-blind, placebo-controlled evaluation. Pain Physician 2004; 7:411-417.

72. Manchikanti L, Pampati V, Damron KS, McManus CD, Jackson SD, Barnhill RC Martin JC. A randomized, prospective, double-blind, placebo-controlled evaluation of the effect of sedation on diagnostic validity of cervical facet joint pain. Pain Physician 2004; 7:301-309.

73. Manchikanti L, Pampati V, Damron KS, McManus CD, Jackson SD, Barnhill RC,
Martin JC. The effect of sedation on diagnostic validity of facet joint nerve blocks: An evaluation to assess similarities in population with involvement in cervical and lumbar regions. Pain Physician 2006; 9:47-52.

74. Manchikanti L, Pampati V, Damron KS The role of placebo and nocebo effects of perioperative administration of sedatives and opioids in interventional pain management. Pain Physician 2005; 8:349-355.

75. Manchikanti L, Boswell MV, Manchukonda R, Cash KA, Giordano J. Influence of prior opioid exposure on diagnostic facet joint nerve blocks. I Opioid Manage 2008; in press.

76. West S, King V, Carey TS, Lohr KN, McKoy N, Sutton SF, Lux L. Systems to Rate the Strength of Scientific Evidence, Evidence Report, Technology Assessment No. 47. AHRQ Publication No. 02-
E016. Rockville, MD: Agency for Healthcare Research and Quality, 2002. www. thecre.com/pdf/ahrq-system-strength. pdf

77. Berg AO, Allan JD. Introducing the third U.S. Preventive Services Task Force. Am J Prev Med 2001; 20:21-35.

78. Cucuzzella TR, Delport EG, Kim N, Marley J, Pruitt C, Delport AG. A survey: Conscious sedation with epidural and zygapophyseal injections: Is it necessary? Spine J 2006; 6:364-369.

79. Kim N, Delport E, Cucuzella T, Marley $J$, Pruitt C. Is sedation indicated before spinal injections. Spine 2007; 32:E748E752.

80. Manchikanti L, Giordano J. Re: Kim N, Delport E, Cucuzzella T, Marley J, Pruitt C. Is sedation indicated before spinal injections? Spine 2008; 33:1157-1158.

81. Colson JD. The pharmacology of sedation. Pain Physician 2005; 8:297-308. 